\title{
Antioxidant Content of Palm Fruit (Borassus flabellifer L.) Seed Coat
}

\author{
Janti Sudiono* and Gabriella Rosetika Susanto \\ Oral Pathology Department, Indonesia
}

*Corresponding author: Janti Sudiono, Oral Pathology Department, Faculty of Dentistry, Trisakti University, Jakarta,

Indonesia

\section{ARTICLE INFO}

Received: 幽 February 22, 2021

Published: March 04, 2021

Citation: Janti Sudiono. Antioxidant Content of Palm Fruit (Borassus flabellifer L.) Seed Coat. Biomed J Sci \& Tech Res 34(3)2021. BJSTR. MS.ID.005540.

Keywords: Antioxidant Activity; B.flabellifer Seed Coat; Ethanol Extract; DPPH Assay

\begin{abstract}
Background: Sunlight, cigarette smoke, and pollution substances triggered free radicals to get into the body. Antioxidant has functions to against free radicals. Borassus flabellifer ( $B$. flabellifer) contains antioxidants however there is no study about the content of their wasted B. flabellifer seed coat. Aim: This study aims to determine antioxidant content of B.flabellifer seed coat ethanol extract using DPPH (2,2-diphenyl-1picrylhydrazy [) assay. Methods: This in vitro experimental study was conducted by three main stages. First stage was B.flabellifer seed coat ethanol extract preparation. Second stage was the quantitative phytochemical tests. At the third stage, antioxidant activity was tested with DPPH assay using the DPPH powder as the free radical toward the seven groups which were negative control of the blank solution, ethanol extract of B.flabellifer seed coat concentration of 3 ppm, 6 ppm, 9 ppm, 12 ppm, 15 ppm, and positive control of gallic acid. Results: B.flabellifer seed coat ethanol extract contains antioxidant groups of flavonoid, phenol, and tannins. B.flabellifer seed coat ethanol extract and control positive of gallic acid has average $\mathrm{IC}_{50}$ of $12,29 \mathrm{ppm}$ and $0,96 \mathrm{ppm}$ respectively. B.flabellifer seed coat ethanol extract and gallic acid showed a strong antioxidant characteristic. Conclusion: B.flabellifer seed coat ethanol extracts contain antioxidant groups of flavonoid, phenol, and tannins and has a very strong antioxidant characteristic. However, have not surpassed the gallic acid as positive control.
\end{abstract}

\section{Introduction}

Antioxidants or anti-free radicals are molecules that are formed due to the presence of free radicals that give their electrons and combine with free electrons from other molecules or other nonradical molecules. The combination reaction between molecules and non-free radical molecules forms a chain reaction [1]. Antioxidant are divided into natural antioxidants and synthetic antioxidants [2]. According to the Public Health of Harvard School, antioxidants have thousands of groups such as flavonoids, phenol, polyphenols, glutathione, lipid acids, and others. The human body needs antioxidants to ward off free radicals that can be obtained from sun exposure, pollution, and cigarette smoke. Indonesia has quite a lot of fruit diversity. There are more than 329 types of fruit found either from Indonesia or immigrants from outside Indonesia. One of the fruits that grow in Indonesia is palm fruit (Borassus flabellifer L.). There are 2800 types of palm trees in the world, 460 species of palm trees grow in Indonesia. One of the 460 species of palm trees is the palm fruit tree [3]. Palm fruit grows in tropical areas such as NTT (East Nusa Tenggara), NTB (West Nusa Tenggara), South Sulawesi, Southeast Maluku, Madura, Bali, Central Java, and East Java (Figure 1) [4]. Palm fruit grows from trees that have a height of up to 30 meters and usually grows on sandy soil $[5,6]$. Meanwhile, every part of the palm fruit such as roots, stems, leaves, and treetops can be used.

Indonesian people usually only consume the fruit, and the seed coat is removed so that the seed coat in the palm fruit becomes trash. In previous studies, palm fruit contains natural antioxidants, especially xanthophylls and phenols groups [7,8]. However, until now, there has been no research on the presence of antioxidants in the seed coat (endocarp) of Borassus flabellifer L. fruit (Figure 2) [9]. Based on the background, researcher interested in examining the antioxidant content within the seed coat of B.flabellifer fruit. 


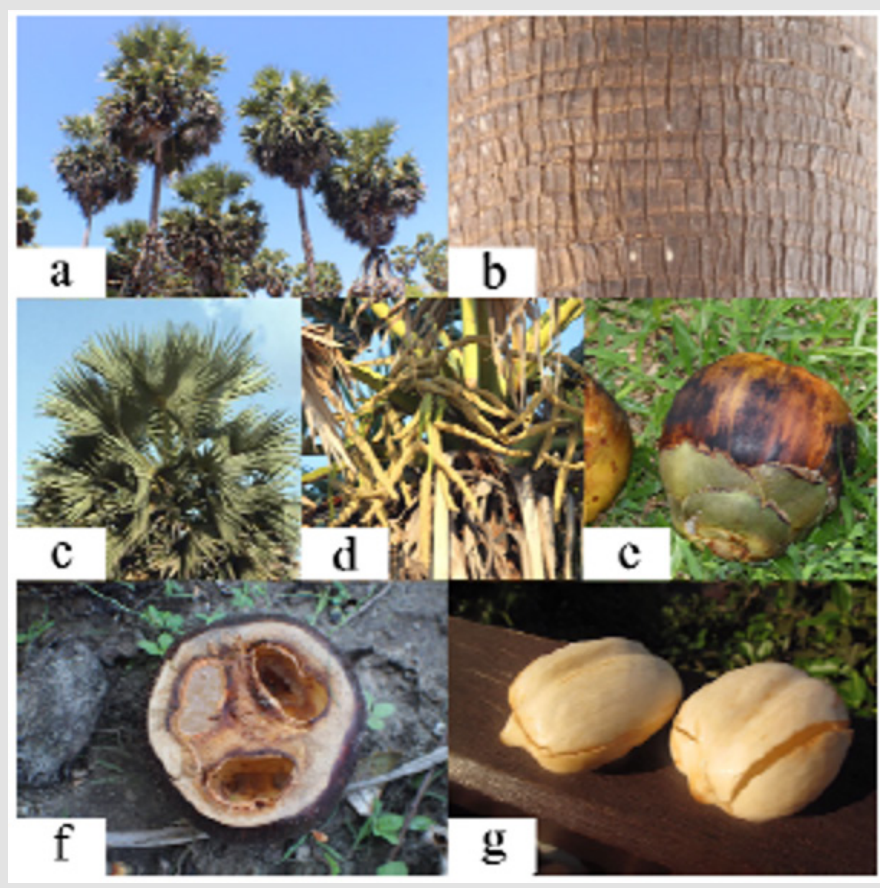

Figure 1:
a. B.flabellifer tree,
b. B.flabellifer stick
c. B.flabellifer leaves,
d. B.flabellifer flowers.
e. B.flabellifer fruit,
f. Inner part of B.flabellifer fruit,
g. Seed coat (endocarp) of B.flabellifer fruit.

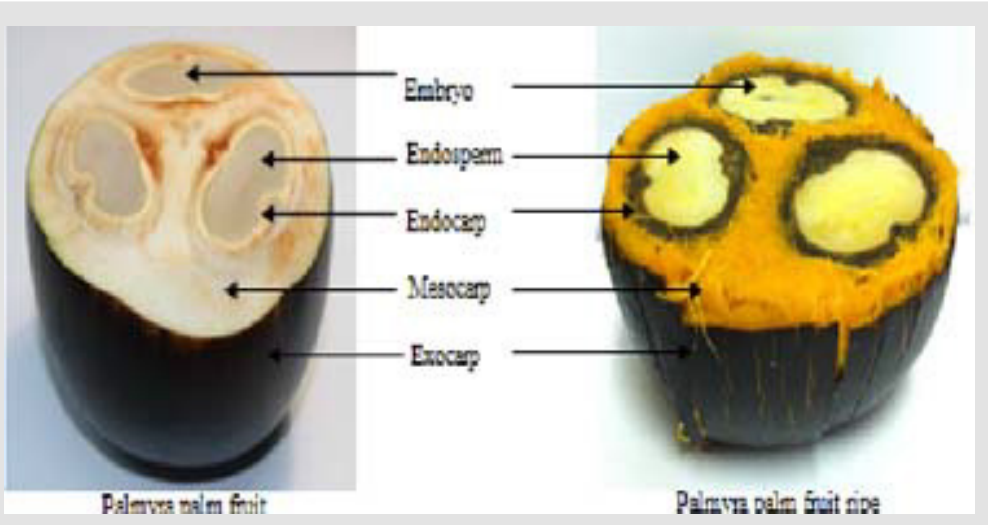

Figure 2: Palmyra palm fruit young (left) and palmyra palm fruit ripe (right) [9].

\section{Materials and Methods}

This laboratory experimental research used the seed coat of B. flabellifer from Tuban, East Java as sample material. The determination herbal test was done at the Indonesian Institute of Sciences (LIPI). The quantitative phytochemical tests of extracts and the measurement of antioxidants content by DPPH method was carried out at the Herbal Laboratory of YARSI University.

\section{Extract Preparation by Maceration Technique}

Young B. flabellifer was washed under running water. Remove the seed coat and outer skin with a knife. Then, the seed coat of $B$. flabellifer was dried at room temperature for 4-5 days, soaked in $70 \%$ ethanol solvent and stirred for 6 hours with a digital shaker. Finally, the extract is filtered with filter paper and evaporated with a rotary vacuum evaporator until thick. 


\section{Phytochemical Test}

\section{A. Flavonoids}

The $0.25 \mathrm{~mL}$ of ethanol extract of B.flabellifer seed coat was piped and added $2.45 \mathrm{~mL}$ of aquabidest into the test tube. Added $0.15 \mathrm{~mL}$ of $5 \% \mathrm{NaNO}_{2}$ solution and incubated for 5 minutes. Added $0.15 \mathrm{~mL}$ of $10 \% \mathrm{AlCl}_{3}$ and incubated again for 6 minutes. Added $2 \mathrm{~mL}$ of $1 \mathrm{M}$ $\mathrm{NaOH}$ and incubated for 15 minutes. The solution was measured at a wavelength of $510 \mathrm{~nm}$ with a UV-Vis spectrophotometer.

\section{B. Phenol}

The $0.25 \mathrm{~mL}$ of ethanol extract of B.flabellifer seed coat was piped and added $3.75 \mathrm{~mL}$ of aquabidest, $0.25 \mathrm{~mL}$ of FolinCiocalteu $50 \%$ reagent and shaken with a vortex shaker. The mixture was incubated for 5 minutes at room temperature. Added $0.75 \mathrm{~mL}$ of $5 \% \mathrm{Na}_{2} \mathrm{CO}_{3}$, stirred and incubated for 60 minutes. The solution was measured at a wavelength of $725 \mathrm{~nm}$ with a UV-Vis spectrophotometer.

\section{Tannins}

The $0.05 \mathrm{~mL}$ ethanol extract of B.flabellifer seed coat piped and added $4.850 \mathrm{~mL}$ aquabidest into the test tube. Added $0.05 \mathrm{~mL}$ $\mathrm{K}_{3}\left[\mathrm{Fe}(\mathrm{CN})_{6}\right] 0.008 \mathrm{M}$ and $0.05 \mathrm{~mL}$ of $0.1 \mathrm{M} \mathrm{FeCL3}$, shaken with a vortex shaker and incubated for 5 minutes. The solution was measured at a wavelength of $700 \mathrm{~nm}$ with a UV-Vis spectrophotometer.

\section{Free Radicals Scavenging (DPPH Method)}

The ethanol extract of B.flabellifer seed coat, methanol, and 160 ppm DPPH was combined into the test tube and incubated for 30 minutes after added the DPPH solution. The solution was measured at a wavelength of $517 \mathrm{~nm}$ with a UV-Vis spectrophotometer.

\section{E. Data Analysis}

Data analysis was performed by calculating the percentage of inhibition with the formula:

$\%$ inhibition $=\frac{A_{0}-A_{1}}{A_{0}} \times 100$

$\mathrm{A}_{0}=$ blank absorbance (methanol)

$A_{1}=$ pabsorbance of the sample (ethanol extract of B.flabellifer seed coat)

Then, calculate the $\mathrm{IC}_{50}$ which is obtained from the linear regression $\mathrm{y}=\mathrm{ax}+\mathrm{b}$ with the formula

$$
I C_{50}=\frac{50-a}{b}
$$

\section{Results}

Total of Flavonoids, Phenols, and Tannins was shown on Table 1.

\section{Free Radicals Scavenging 1ith DPPH Method}

The DPPH test was carried out at several concentrations of the ethanol extract of B.flabellifer seed coat, namely 3 ppm, 6 ppm, 9 ppm, 12 ppm, 15 ppm, and gallic acid as positive control. The test was carried out three times (Table 2 \& Graph 1 ).

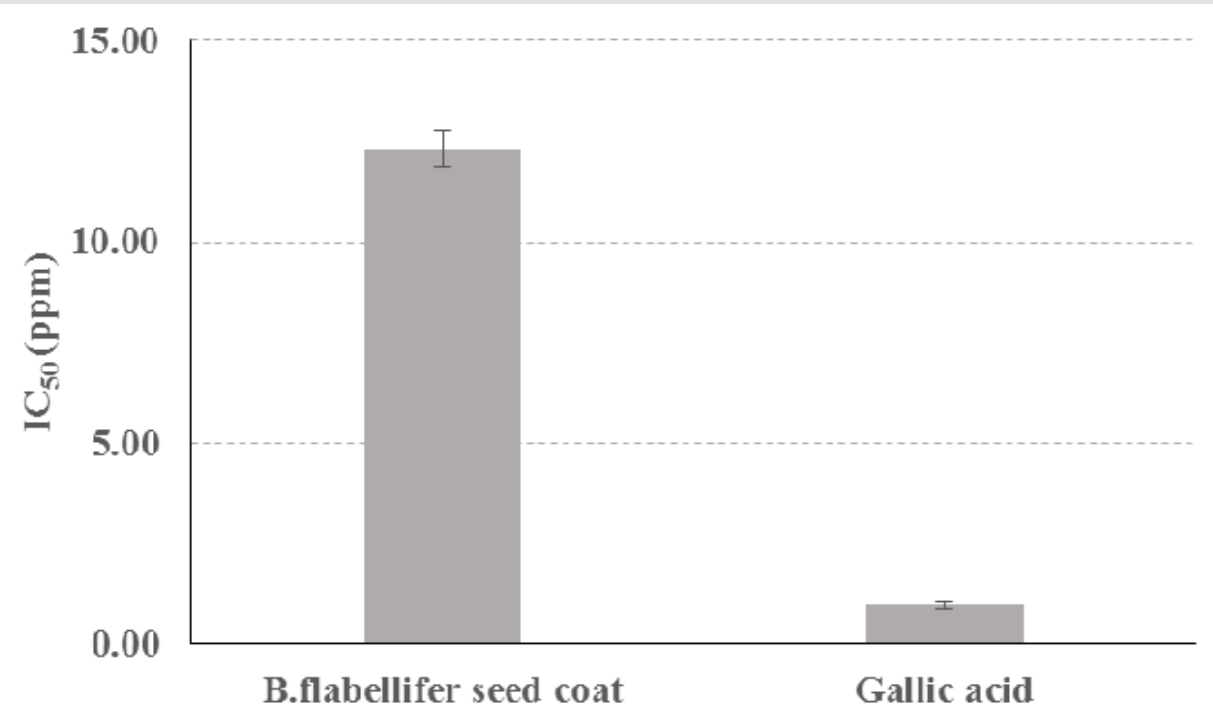

Graph 1: $\mathrm{IC}_{50}$ average of B.flabellifer ethanol extract and Gallic acid. 
Table 1: Quantitative Phytochemical Test.

\begin{tabular}{|c|c|c|c|c|}
\hline Sample & Parameter & Result & Unit & Technique Analyze \\
\hline & Flavonoid & $112.14+0.31$ & mg RE/g extract & \\
\hline \multirow[t]{2}{*}{$\begin{array}{l}\text { Ethanol extract of } \\
\text { B.flabellifer seed coat }\end{array}$} & Phenol & $163.90+0.51$ & mg GAE/g extract & $\begin{array}{l}\text { Colorimetry and } \\
\text { Spectrofotometry }\end{array}$ \\
\hline & Tannins & $134.62+2.76$ & mg TAE/g extract & \\
\hline
\end{tabular}

Table 2: Measurement of Absorbance, Inhibition Percentage, and Average $\mathrm{IC}_{50}$ of Ethanol Extract of B.flabellifer and Gallic Acid.

\begin{tabular}{|c|c|c|c|c|c|c|}
\hline Sample & Test & $\begin{array}{c}\text { Concentration } \\
\text { (ppm) }\end{array}$ & Absorb ance & Inhibition \% & $\mathrm{IC}_{50}$ & $\begin{array}{c}\text { IC }_{50} \\
\text { Average }\end{array}$ \\
\hline Blank & - & - & 0.095 & - & - & - \\
\hline & 1 & 3 & 0.773 & 14.59 & \multirow{5}{*}{12.72} & \\
\hline & & 6 & 0.687 & 24.09 & & \\
\hline & & 9 & 0.587 & 35.14 & & \\
\hline & & 12 & 0.457 & 49.5 & & \\
\hline & & 15 & 0.384 & 57.57 & & \\
\hline \multirow{10}{*}{$\begin{array}{l}\text { Ethanol } \\
\text { Extract of } \\
\text { B.flabellifer } \\
\text { Seed Coat }\end{array}$} & \multirow{5}{*}{2} & 3 & 0.789 & 12.82 & \multirow{5}{*}{11.83} & \multirow{5}{*}{$12.29+0.44$} \\
\hline & & 6 & 0.664 & 26.63 & & \\
\hline & & 9 & 0.554 & 38.78 & & \\
\hline & & 12 & 0.457 & 49.5 & & \\
\hline & & 15 & 0.33 & 63.54 & & \\
\hline & \multirow{5}{*}{3} & 3 & 0.778 & 14.03 & \multirow{5}{*}{12.31} & \\
\hline & & 6 & 0.658 & 27.29 & & \\
\hline & & 9 & 0.544 & 39.89 & & \\
\hline & & 12 & 0.446 & 50.72 & & \\
\hline & & 15 & 0.386 & 57.35 & & \\
\hline \multirow[t]{6}{*}{ Blank } & - & - & 0.744 & - & - & - \\
\hline & \multirow{5}{*}{1} & 0,25 & 0.659 & 7.31 & \multirow{5}{*}{1.05} & \\
\hline & & 0,5 & 0.551 & 22.5 & & \\
\hline & & 0,75 & 0.473 & 33.47 & & \\
\hline & & 1 & 0.376 & 47.12 & & \\
\hline & & 1,25 & 0.282 & 60.34 & & \\
\hline \multirow{10}{*}{ Gallic Acid } & \multirow{5}{*}{2} & 0.25 & 0.65 & 12.63 & \multirow{5}{*}{0.9} & \multirow{5}{*}{$0.96+0.08$} \\
\hline & & 0.5 & 0.537 & 27.82 & & \\
\hline & & 0.75 & 0.453 & 39.11 & & \\
\hline & & 1 & 0.301 & 59.54 & & \\
\hline & & 1.25 & 0.234 & 68.55 & & \\
\hline & & 0.25 & 0,668 & 6.05 & & \\
\hline & & 0.5 & 0,566 & 20.39 & & \\
\hline & 3 & 0.75 & 0,438 & 38.4 & 0.92 & \\
\hline & & 1 & 0,316 & 55.56 & & \\
\hline & & 1.25 & 0,199 & 72.01 & & \\
\hline
\end{tabular}

\section{Discussion}

In study of antioxidant activity, it is necessary to consider the effect of the solvent, the method of extraction, the method of antioxidant content measurement, the wavelength, and the absorbance value used to calculate the percentage of inhibition. This needs to be considered because solvents have different variations and have polar or non-polar properties. This study used ethanol $70 \%$ as polar and nontoxic solution. Then, the extraction method by maceration technique used in this study with the reason that by maceration for 3 days the phytochemical content will be able to penetrate through the rupture of cell membrane. The antioxidant activity can be determined by several methods. Each method uses different wavelengths, such as DPPH (2,2-diphenyl-1- 
picrylhydrazyl) measured with a maximum wavelength of 520 nm, ABTS (2,2'- azino-bis(3-ethylbenzothiazoline-6-sulfonate) wavelength $743 \mathrm{~nm}$, and CUPRAC (Cupric Reducing Antioxidant Power) with a wavelength of $450 \mathrm{~nm}$ [10]. This research used the DPPH method because the DPPH method has advantages, namely it is easy to do, effective, and a good way to study plant extracts [11]. Finally, the absorbance value is largely determined by the wavelength used when measuring the absorbance of a certain concentration with a UV-Vis spectrophotometer that was used in this study. This study used wavelength of $517 \mathrm{~nm}$.

Ethanol extract of B.flabellifer seed coat contained flavonoids, phenols, and tannins. Flavonoids have biological effects as antioxidants, anti-inflammatory, anti-cancer, and anti-proliferative. Phenol has antioxidant, anti- inflammatory, anti-carcinogenic, anti-cancer, and anti-viral properties. Tannins has antioxidant, antimicrobial, antibacterial, and anti-viral properties. Based on the indicator of antioxidant properties of Molyneux (2004), the ethanol extract of B.flabellifer seed coat and Gallic acid categorized as very strong properties because they both have $\mathrm{IC}_{50}$ below $50 \mathrm{ppm}$. In previous studies, B.flabellifer leaves had an inhibition percentage of $42.01 \%$ at a concentration of $20 \mathrm{ppm}$ [12]. In the ethanol extract of B.flabellifer seed coat with a concentration of $15 \mathrm{ppm}$ had an inhibition percentage of $59.49 \%$. Based on these results, it can be seen that the ethanol extract of B.flabellifer seed coat has a higher free radical scavenging power than those of the B.flabellifer leaves. Research on antioxidant activity has also been carried out on young B.flabellifer fruit flesh with the smallest concentration, namely $312.5 \mathrm{ppm}$, getting a percentage of inhibition as much as $30.22 \%$ [13]. In this study, the largest concentration ethanol extract B.flabellifer seed coat used of $15 \mathrm{ppm}$ showed the inhibition percentage as much as $59.49 \%$. Based on the above results, it can be seen that the value of antioxidant activity in young B. flabellifer fruit flesh with a concentration of $15 \mathrm{ppm}$ is smaller than those of ethanol extract $B$. flabellifer seed coat.

\section{Conclusion}

The ethanol extract B.flabellifer seed coat contains flavonoids, phenols, and tannins. Based on the indicator of Molyneux antioxidant properties, the ethanol extract B.flabellifer seed coat

\section{ISSN: 2574-1241}

DOI: 10.26717/BJSTR.2021.34.005540

Janti Sudiono. Biomed J Sci \& Tech Res

This work is licensed under Creative Commons Attribution 4.0 License

Submission Link: https://biomedres.us/submit-manuscript.php has very strong properties. The ethanol extract B.flabellifer seed coat can outperform the inhibition percentage of B. flabellifer leaves and young B.flabellifer pulp, but it has not been able to outperform the antioxidant activity of the positive control, namely gallic acid.

\section{References}

1. Yuslianti ER (2018) Pengantar Radikal Bebas dan Antioksidan. Deepublish, Yogyakarta, Indonesia, pp. 122.

2. Rahmatika A Ashitaba (Angelica keiskei Koidz (2017) Dengan Setil Alkohol sebagai Stiffening Agent [Skripsi]. Fakultas Kedokteran dan Ilmu Kesehatan Uin Syarif Hidayatullah, Jakarta, Indonesia.

3. Artiningsih NKA, Irawan TAB, Wisnu RTD (2014) Optimasi Metode Ekstraksi Antosianin Limbah Kulit Buah Siwalan (Borassus flabellifer) Untuk Pewarna Alami Bahan Pangan dan Aplikasinya Pada Pembuatan Sari Buah Jeruk. Open J Syst 3(2): 15.

4. Apriyanti IR (2018) Studi Potensi Pemanfaatan Limbah Serat Batok Siwalan (Borassus flabellifer L) Sebagai Bahan Baku Kerajinan Lokal (Benang) Gresik. APERTI BUMN Aliansi Perguru Tinggi BUMN 1(1): 8.

5. Konay SM, Pakan PD, Kareri DGR (2019) Uji Potensi Anti Bakteri Ekstrak Etanol 70\% Buah Lontar (Borassus flabellifer) terhadap Pertumbuhan Staphylococcus aureus. Cendana Med J 7(2): 14.

6. Umam MSA (2018) Pengaruh Konsentrasi Ragi Roti (Saccharomyces cerevisiae) dan Waktu Fermentasi terhadap Kadar Bioetanol Nira Siwalan (Borassus flabellifer L) [Skripsi]. Malang: Fakultas Sains dan Teknologi Universitas Islam Negeri Maulana Malik Ibrahim.

7. Amatullah L, Cahyaningrum TN, Fidyaningsih AN (2017) Antioxidants Effectivity In Skin Lotion Formulation of Mesocarp Fruit Extract Lontar (Borassus Flabellifer) against White Rats Wistar Male In-Situ. JPSCR J Pharm Sci Clin Res 2(01): 25.

8. Abdullah F (2018) Total Phenolic Contents and Antioxidant Activity of Palm Oils and Palm Kernel Oils At Various Refining Processes. J Oil Palm Res 30: 682-692.

9. Artnarong S, Masniyom P, Maneesri J (2016) Isolation of yeast and acetic acid bacteria from palmyra palm fruit pulp Borassus flabellifer Linn.). International Food Research Journal 23(3): 1308-1314.

10. Pisoschi AM, Negulescu GP (2012) Methods for Total Antioxidant Activity Determination: A Review. Biochem Anal Biochem 01(01).

11. Badarinath AV, RAo KM, Chetty CMS, Ramkanth S, Rajan TVS, et al. (2010) A Review on In-vitro Antioxidant Methods: Comparisons, Correlations and Considerations. Int J PharmTech Res 2(2): 10.

12. Jamkhande PG, Suryawanshi VA, Kaylankar TM, Patwekar SL (2016) Biological Activities of Leaves of Ethnomedicinal Plant, Borassus flabellifer Linn (Palmyra palm): An Antibacterial, Antifungal and Antioxidant Evaluation. Bull Fac Pharm Cairo Univ 54(1): 59-66.

13. Singchai B, Kansane K, Chourykaew B (2015) Phytochemical Screening and Biological Activities of Borassus Flabellifer L. Asian J Pharm Clin Res 8(3): 4 .

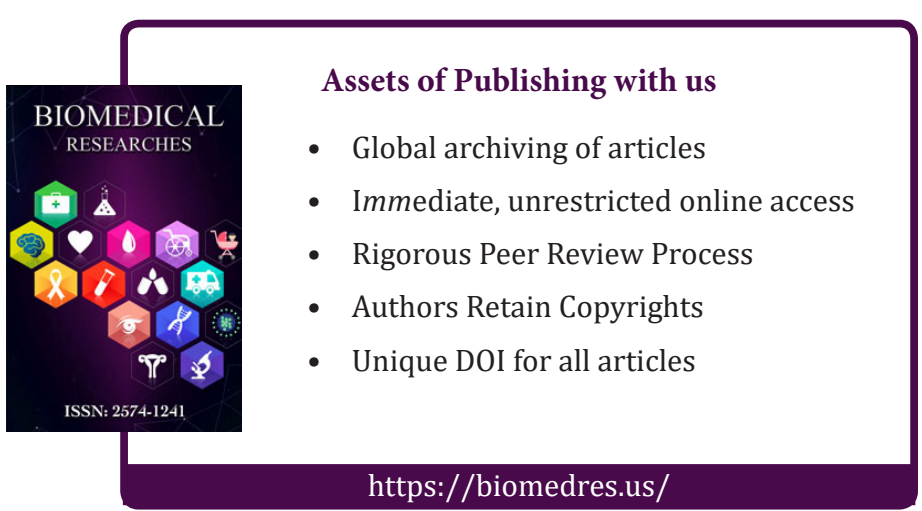

